\title{
"Follow me": the life of courtesans and virgins in the classical world
}

\section{Lesley Smith}

\section{Women's position in society}

"Women are by no means inferior to men," said Socrates, showing that some people in the ancient world recognised women as being equal to men. This was said at a time when, in Athens, women had fewer rights than slaves, being beholden to the absolute authority of their male kin. Analysis of that statement shows that Socrates recognised the possible power of women within the society he knew so well, and much of that power was vested in prostitutes.

Within the army of prostitutes were many ranks: from the gutter girl who for bread or the equivalent of a few pence would perform sexual services, right up to the professional courtesan. In history, these individuals were usually rich, beautiful and talented in a number of ways. From emperors to kings, the courtesans often had great influence, sometimes above and beyond that of the wife. It is not difficult or complex to understand, but nevertheless interesting, how these women - and sometimes men - were almost non-human in the way society reacted to them. They were above - or below - the usual roles of gender, as Socrates' comment illustrates.

\section{Greek courtesans}

In ancient Greece, the top-level courtesans were the hetairai (from the Greek word meaning companion), who had to gain recognition to attain that professionally recognised status. Happily letters and poems help us see something of the life of the hetairai, as do some works of art. To have physical beauty and be highly skilled and adventurous sexually was not enough; these girls also had to be able to entertain the mind with an understanding of politics and the arts, particularly literature. Their homes were likely fashionable and extremely comfortable, with hangings and perfumed fountains, so that clients could be entertained and indeed bring their friends along for an evening of delights. Food and drink of the highest standard would be on offer from, in some cases, a surprisingly great number of servants and slaves. This was all at great cost to the client, of course, and in the endless desire of men to compete, the higher the cost, the greater the desirability.

The hetairai also had to be very careful not to fall into the wrong hands, as the dark side of the prostitute economy flourished in Greece and Rome and the threat to life with poison or a dagger was a real risk. History shows these women working in a businesslike manner in the 6th century $\mathrm{BC}$. There is even evidence of uprisings in Athens society against the hetairai, as they held such sway with some of the political figures of the day.

The existing artworks that celebrate the lives of these women are commonly reproduced on those rather dubious pottery drinks coasters that are hidden in the bottom of many a modern suitcase returning from a holiday in Greece. These reproductions show real illustrations, in many cases taken from original vases and bowls to be found in museums and galleries around the world.

J Fam Plann Reprod Health Care 2009; 35(4): 260-261

Tutbury Castle, Tutbury, UK

Lesley Smith, Curator

Correspondence to: Lesley Smith, Tutbury Castle, Tutbury, Staffordshire DE13 9JF, UK. E-mail: info@tutburycastle.com
The sexually athletic skills of the hetairai were indeed admirable if the art be true to life and not just an opportunity to create pornography for an eager market. They show a range of positions during sexual intercourse, sometimes involving more than two willing participants, and acts such as fellatio can also be seen. Same-sex scenes are common, as evidenced by images of older men with what appear to be teenage boys.

It seems the courtesans 'traded' with a few key clients, and in some cases took on an almost mistress role with just the one client, who would keep her financially and protected her interests. In some cases there is even love apparent on both sides of the relationship.

Advertising, in terms of personal adornment with perfumes, cosmetics and dyed hair - particularly, it seems, a bright yellow or henna red - worked then as it still does today: by offering a suggestion of the exotic or unusual.

\section{Roman courtesans}

In classical Rome, powerful courtesans worked in effectively the same way as in Greece. There are pavement carvings in Pompeii with a heart carved and peppered with holes on one side telling the prospective client that her heart is broken, but there is still room for him if he would just step this way. My personal favourite piece of marketing is the delicate sandal that still exists and is studded on the sole. As the prostitute walked in the dusty streets the studs would spell out the words "Follow Me". One wonders if occasionally there would be a small queue at her door.

Religion played its part in sexual behaviour; the goddess of love - Venus or Aphrodite, giving her Roman and Greek names, respectively - had a need for handmaidens and priestesses within her temples. Sexual ritual under a cover of pious respect for the needs of Venus or Aphrodite made her temple rather more fun to belong to than some. Unsurprisingly, a large number of high-ranking courtesans were attached to the temples of love. Aphrodite was considered the Mother of the Nation, guardian of marriage and patron of all harlots.

Venus enjoyed annual festivals in Rome; she was worshipped on 1st April by women who were married and on 23rd April by harlots - of both sexes, as male prostitutes flourished in Greece and Rome. Venus was the great force of life in Roman society: the mother of the people and the great lover who had flowers springing from under her feet where she walked.

\section{Festivals and fetishes}

It would be quite wrong, however, to think that sexual experimentation was only the province of the harlots and brothel keepers. There are records of an extraordinary period in Roman history that affected some unexpected sectors of society. Roman citizens who were seeking sexual thrills of the darkest type became initiates of Bacchus, who was the Pan-like god of the revels. His followers brought such chaos on some nights in Rome that the Senate were forced to make the worship of Bacchus illegal. What is a surprise is the original thrice-yearly festivals were celebrated by women and supervised by Roman matrons. After a short time, men were admitted and then celebration took place more frequently, four or five times a month. 
Sexual restraint was thrown off by the women, who were involved in the rape of young men, torture, drunken orgies and even the murder of some individuals who refused to take part. There was screaming and rioting and women described as having their hair on fire. Revelations eventually spilled out, and according to one Roman observer 7000 people - many from the highest levels of society - were arrested; and whilst the women were taken back by their families, the men were executed.

\section{Vestal virgins}

No wonder virginity could be a safer option. Most of us have heard of the Vestal Virgins. Vesta was the goddess of the hearth, and was commonly found as a statue deity on a little alcove in Roman households. Offerings could be found at her feet in return for her protection of the household.

There could only be six Vestal Virgins working in the temple and they were chosen at the age of 10 years or under (to ensure virginity) from the wealthiest families in Rome. Interestingly, the property of a Vestal Virgin passed to the state, which might explain why they were selected from such families! These young girls were initiated as priestesses to serve and protect the hearth of Rome itself amongst other duties. This enforced life of chastity would last for 30 years and at the end of this time they were released into society for retirement, at approximately 40 years of age. Many families tried desperately to avoid their girls appearing on the list of candidates, and bribery to avoid this honour was not unknown. The morals of the Vestal Virgin were considered of national importance: if Rome suffered defeat, the Vestal Virgins might be under suspicion, so great was the belief in their protective potency.

\section{Some things never change}

Prostitution has always been particularly successful where there has been a good deal of transit traffic: in ports, markets and courts of all types. Corinth alone boasted more than a thousand hetairai working in the temple of Aphrodite, and it was considered pious to dedicate more and thereby win the approval and protection of the goddess herself.

In Rome, Ovid in the 1st century AD wrote The Erotic Poems. They speak of love, passion and sexual need. These poems are extraordinary as they give so much detail of human desire in classical Rome. What is certain, however, is that very little has changed in the human condition - it is just a matter of what society, including religion, will allow in the interpretation of such desires.

\section{Future articles}

This article is the first of a series of three articles; the second article will be based in the Tudor court and the final one in Restoration England.

\section{Acknowledgement}

The author would like to thank Dr G Williams, British Museum, London, UK for his help and advice.

\section{Bibliography}

1 Tannahill, Reay. Sex in History. London, UK: Abacus, 1989.

2 Homer. The Illiad (Penguin Classics). London, UK: Penguin Books, 2003.

3 Homer. The Odyssey (Penguin Classics). London, UK: Penguin Books, 2003.

4 Ovid. The Erotic Poems (Penguin Classics). London, UK: Penguin Books, 2004.

About the author

Lesley Smith is currently a postgraduate student in the Centre for the History of Medicine of the University of Birmingham, where she is developing a $\mathrm{PhD}$ in obstetrics and gynaecology in early modern Britain. She holds an honorary degree for "services to history". She makes 200-300 public appearances a year and also works as a TV historian in the UK and abroad including the USA. Lesley is also Curator of Tutbury Castle in Staffordshire and is currently involved with a major research project with the British Museum, which is her excuse for why it is taking her so long to finish her $\mathrm{PhD}$ !

\section{FACULTY OF SEXUAL \& REPRODUCTIVE HEALTHCARE MEMBERSHIP EXAMINATION}

The Membership Examination (MFSRH) consists of:

\section{Part 1 Multiple Choice Question paper (MCQ)}

This 11/2-hour paper consists of 60 clinical science and applied science questions.

The examination date(s) for the London-based examination are still to be confirmed, but details will appear on the Faculty of Sexual and Reproductive Healthcare website in due course (www.fsrh.org).

\section{- Evidence Based Commentary (EBC)}

The Evidence Based Commentary replaces the case reports/dissertation component of the Membership examination and candidates can now view the first annually released topic on the Faculty website. Candidates had an absolute deadline of $\mathbf{3 1}$ August 2009 to submit the Commentary on this topic. The Commentary must be a minimum of 1000 words and a maximum of 2000 words, excluding references, tables and appendices, and the format must follow the guidance notes. Candidates can find detailed information in the Candidate Guidance Notes for Evidence Based Commentary and the Membership Examination Regulations (September 2008) on the Faculty website.

\section{- Part 2 Examination (CRQ, SAQ, OSCE)}

This all-day examination consists of:

- Critical Reading Question examination paper (CRQ)

- Short Answer Question examination paper (SAQ)

- Objective Structured Clinical Examination (OSCE)

The Faculty must receive applications for the MFSRH Part 2 held in June 2010 by 3 January 2010. Information on the Part 2 examination, the Examination Regulations and the application form appear on the Faculty website.

The qualification is subject to re-certification every 5 years.

For the current MFSRH Examination Regulations (September 2008), information on all components of the MFSRH examination and application forms, please visit the FSRH website: www.fsrh.org (see Training \& Exams, Membership Exam) or e-mail Denise Pickford at denise@fsrh.org. 